\title{
The sources of contamination and reasons for damage of the flow part of the marine turbine engine in operation
}

\begin{abstract}
The aim of this paper is to show particular sensitivity of the flow part of the marine turbine engine to the presence of contaminants in the intake air. The contaminants form hard-to-remove deposits in the intervane channels that result in a reduced efficiency and performance of the engine. The paper classifies the contaminants according to the source of their formation and their destructive force. The performed analyses and syntheses of the discussed problem have been complemented with the results of own endoscopic research of the flow part of various types of marine turbine engines.
\end{abstract}

Keywords: marine turbine engine, flow part, damage identification

\section{Źródła zanieczyszczeń i uszkodzeń części przepływowej okrętowego turbinowego silnika spalinowego podczas jego eksploatacji}

\begin{abstract}
Celem niniejszego artykułu jest wykazanie szczególnej wrażliwości części przepływowej turbinowego silnika spalinowego zabudowanego w siłowni okrętowej na obecność zanieczyszczeń zawartych w powietrzu dolotowym. Tworza one w kanałach międzyłopatkowych sprężarek i turbin trudno usuwalne osady, które zmniejszaja sprawność i osiagi silnika. W artykule sklasyfikowano występujące zanieczyszczenia według źródła powstawania $i$ wedlug charakteru destrukcyjnego oddziaływania na część przepływowa. Przeprowadzone analizy i syntezy rozpatrywanego problemu eksploatacyjnego uzupetniono wynikami własnych badań endoskopowych częśsi przeplywowej różnych typów turbinowych silników okrętowych.
\end{abstract}

Słowa kluczowe: okrętowy turbinowy silnik spalinowy, część przeptywowa, identyfikacja uszkodzeń

\section{Introduction}

There are many requirements related to the application of turbine engines in marine powertrains that ensure long lasting and reliable operation of the machinery. Turbine engines at sea must operate under storm conditions accompanied by permanent vertical, longitudinal and transverse sway as well as longitudinal and transverse oscillations of the hull.

During an intense sea swell, despite the forces exerted on the bearings of the engine rotors a serious danger is the possibility of the ingression of seawater into the flow part of the engine in large amounts $[2,5]$.

The sea pyrosol sucked in by the engine air intake (dry air containing solid mineral particles and liquid water particles in which mineral salts are dissolved) carries all the contaminants to the flow channels, which leads to a formation of deposits. The sea pyrosol is generated as a result of the wind and the ship acting on the sea surface.

Another problem is the possibility of the presence of exhaust gases in the pyrosol sucked in by the engine. The exhaust gases come from the same engine (dysfunction of the labyrinth seals) or their source could be another marine engine of the main or auxiliary units of the ship. As a consequence, the energy-related indexes of the marine turbine engines and their external and internal characteristics are subject to continuous changes in time. This process is unavoidable whose dynamics and nature of progress are tightly related to the widely understood conditions of operation. The scale of this phenomenon is also influenced by the design of the air intakes, the intake and exhaust ducts, the dedust-

\section{Wprowadzenie}

Zastosowanie turbinowych silników spalinowych w okrętowych układach napędowych stawia przed użytkownikiem wiele specyficznych wymagań gwarantujących ich długotrwałą i bezawaryjną pracę. Użytkowanie w warunkach morskich wymaga zdolności do kontynuowania pracy układu napędowego podczas żeglugi okrętu w sztormowych warunkach pogodowych, której towarzyszy permanentne kołysanie pionowe, wzdłużne i boczne kadłuba oraz jego oscylacje wzdłużne i poprzeczne.

Podczas intensywnego falowania morza, oprócz oddziaływania znacznych obciążeń mechanicznych na węzły łożyskowe wirników silnika, istotne zagrożenie stanowi możliwość bezpośredniego przedostawania się wody morskiej do części przepływowej silnika - nawet w dość znacznych ilościach [2,5].

Zasysany przez silnik czynnik roboczy, tzw. pyrozol morski (suche powietrze zawierające stałe cząsteczki pochodzenia mineralnego oraz ciekłe cząsteczki wody, w których rozpuszczone są sole mineralne), niosąc ze sobą w głąb kanałów przepływowych różnorodne substancje w nim zawarte, staje się przyczyną powstawania osadów. Pyrozol morski powstaje w wyniku oddziaływania wiatru i ruchu okrętu na powierzchnię morza.

Innym problemem jest możliwość obecności spalin w pyrozolu zasysanym przez silnik. Pochodzą one z samego silnika (dysfunkcja uszczelnień labiryntowych), albo ich źródłem może być inny okrętowy silnik spalinowy napędu głównego lub pomocniczego okrętu. W konsekwencji 
ers and the engine loads. An existing rule when designing a turbine-powered vessel is to place the air intakes closest to the diametrical and midship sections above the sea level ( 8 meters). Their shape and location should reduce the probability of water splash and exhaust gases getting into the intake channels. Modern fast warships (but not only) with a turbine propulsion are equipped with deduster systems that reduce the amount of water and mineral salts getting into the engine intervane channels. Their design and geometry as well as thermal/flow characteristics depend on the design and the parameters of the vessel. The total pressure losses for a clean deduster should not exceed $500 \div 1800 \mathrm{~Pa}$ at the flow velocities of $2.5 \div 10 \mathrm{~m} / \mathrm{s}$. This corresponds to approximately $1 \div 2 \%$ power loss $[5,6]$. Marine engines have an admissible increase in the flow resistance (due to contamination) by $800 \div 1000 \mathrm{~Pa}$, which additionally reduces the engine power output by approximately $1.5 \%[1,2,12]$.

Improper operation of the engine elements (combustors and bearings in particular) may also result in a presence of oil-based products in its flow part. The most disadvantageous is the very process of engine startup i.e. non-steady operating conditions. Such specific elements of the engine as labyrinth seals, fuel feed lines or the combustor may become a source of additional contamination.

When combusting the fuel in the engine a mix of combustion products and air is formed whose proportions and chemical composition are determined by the parameters of the working medium at the intake to the combustor and the quality of fuel and corrosion inhibitors. The nature of the changes of the chemical composition of the working medium along the flow part has been shown in Fig. 1.

The conditions of operation of marine turbine engines can be divided into two basic groups:
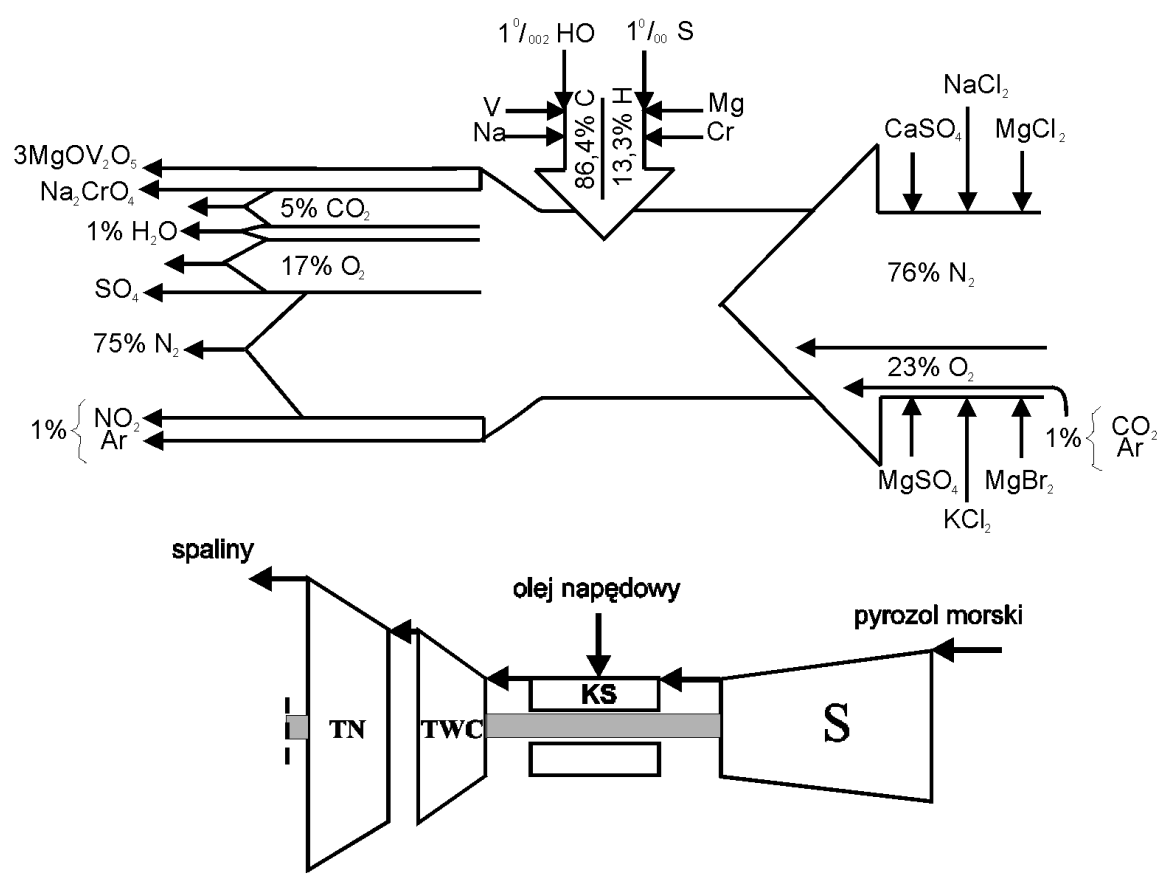

Fig. 1. Changes of the chemical composition of the working medium along the flow part Rys. 1. Charakter zmian sktadu chemicznego czynnika roboczego wzdtuż części przeptywowej wskaźniki energetyczne okrętowych turbinowych silników spalinowych, a tym samym ich charakterystyki zewnętrzne i wewnętrzne, ulegają ciągłym zmianom wraz z upływem czasu eksploatacji. Jest to proces nieunikniony, którego dynamika i charakter przebiegu są ściśle uzależnione od szeroko pojętych warunków eksploatacji. O skali tego zjawiska decydują również względy konstrukcyjne przyjętych rozwiązań wlotów powietrza, kanałów dolotowych i wylotowych, zastosowanych odpylaczy oraz obciążenie silnika. Obowiązującą zasadą przy projektowaniu kadłuba okrętu z napędem turbinowym jest usytuowanie wlotów powietrza możliwie najbliżej płaszczyzn diametralnej i owręża okrętu, na wysokości ponad warstwą przywodną ( 8 metrów nad poziomem morza). Ich kształt i usytuowanie powinny ograniczyć do minimum prawdopodobieństwo przedostania się do kanałów silnika mas wody rozbryzgiwanych przez kadłub i spalin wylotowych pracujących maszyn okrętowych. Współczesne szybkie okręty wojenne (i nie tylko) z napędem turbinowym wyposażane są w urządzenia oczyszczania powietrza (odpylacze), które zainstalowane na okręcie, pomiędzy atmosferą otaczającą kadłub i przekrojem wlotowym silnika, zmniejszają ilość wody, a tym samym ilość soli mineralnych przedostających się do kanałów międzyłopatkowych silnika. Ich konstrukcja, kształty i wymiary geometryczne oraz charakterystyki cieplno-przepływowe uwarunkowane są przeznaczeniem i możliwościami okrętu. Straty ciśnienia całkowitego dla czystego odpylacza nie powinny przekraczać $500 \div 1800 \mathrm{~Pa}$, przy prędkościach przepływu rzędu $2,5 \div 10 \mathrm{~m} / \mathrm{s}$. Odpowiada to mniej więcej $1 \div 2 \%$ utracie mocy $[5,6]$. Podczas użytkowania silnika zabudowanego w siłowni okrętowej dopuszczalne normy przewidują zwiększenie oporów przepływu wskutek zanieczyszczenia wkładów filtrujących odpylaczy o $800 \div 1000$ $\mathrm{Pa}$, co dodatkowo zmniejsza moc silnika o około $1,5 \%[1,2,12]$.

Nieprawidłowości w pracy wewnętrznych węzłów konstrukcyjnych silnika (szczególnie komory spalania i przestrzeni łożyskowych) mogą również stać się przyczyną obecności w jego części przepływowej cząstek oleju smarowego i innych produktów ropopochodnych. Najbardziej niekorzystny jest tutaj proces samego uruchamiania silnika, tzn. podczas nieustalonych warunków jego pracy. Takie szczególnie newralgiczne elementy konstrukcji, jak uszczelnienia labiryntowe węzłów łożyskowych, instalacja zasilania silnika paliwem, komora spalania mogą stać się źródłem dodatkowego zanieczyszczenia czynnika roboczego.

Podczas spalania paliwa w silniku tworzy się mieszanina produktów spalania i powietrza, której proporcje i skład chemiczny determinowane są 
1. Ambient conditions:

- the location where the ship is operated (port, characteristics of the waters etc.),

- atmosphere parameters in the aspect of their deviation from the reference atmosphere (ISA).

2. The change in the shape and geometry of the flow channels and the conditions of their surface caused by:

- a reversible process of contamination and an irreversible wear process of corrosion - erosion,

- deformation of the shape of the external engine casing (change in the radial and axial play in the rotor assemblies),

- damage resulting from an incidental presence of foreign objects in the flow part (FOD),

- damage to the subassemblies responsible for the adjustment of the shape and geometry of the flow part (wastegate, reverse mechanism of the separate drive turbine, variable geometry of engine intake, variable geometry of the turbine first stages etc.).

The issue of sensitivity of marine turbine engines to the variability of the widely understood sea conditions of operation is still a very current issue ever since the first applications of this type of powertrain when in 1947 the 'Gatric' engine by British Associated Electrical Industries Ltd. Marked G1 (1840 kW) was used as the peak power engine for the Royal Navy torpedo cutter under the operating number of M.G.B.2009 [3, 4]. It was the sea adaptation of the Metropolitan-Vickers jet engine that was coupled with a free drive turbine. The first sea trials surprised the designers with a very high sensitivity of the engine to the deposits of salts in the intervane channels of the compressor. After approximately 20 hours of operation the power drop was so large that the test had to be stopped. The observed imperfection was remedied only partially by an injection of deionized water into the air at the compressor intake.

\section{The deposit formation mechanism}

Hard to remove deposits continuously sediment on the surfaces of the flow part of the engine and are a reason for permanent drop in the engine efficiency and a serious deterioration of the engine dynamics. The classification of the contaminants according to the source of their formation and according to the nature of their interaction with the flow part has been shown in Fig. 2 .

The mass flow of the working medium running through the flow part of the engine may reach up to $100 \mathrm{~kg} / \mathrm{s}$ for modern engines, which means that with the mass of air also large amounts of salt get through. For the Baltic Sea, where the salt level is low (7.2 $\mathrm{g} / \mathrm{kg}$ on average) and in the air above the water surface the concentration of salt in the air is $0.1 \mathrm{mg} / \mathrm{kg}$ only during one hour of operation of the engine at the nominal load the flow part receives approximately $0.03 \div 0.05 \mathrm{~kg}$ of salt [5].

A portion of the salt only flows through the engine but some of it deposits contaminating its flow channels. The mechanism of the formation of the deposits is as follows: seawater droplets, containing dissolved salt get inside the compressor at the same time intensely evaporating. As- parametrami czynnika roboczego na wlocie do komory spalania, jak również jakością samego paliwa i zastosowanych inhibitorów korozji. Charakter zmian składu chemicznego czynnika roboczego wzdłuż części przepływowej przedstawiono na rys. 1 .

Warunki eksploatacji okrętowych turbinowych silników spalinowych podzielić można na dwie zasadnicze grupy:

1. Warunki otoczenia:

- miejsce użytkowania okrętu (baseny portowe, charakterystyka akwenu pływania itp.),

- parametry atmosfery, w kontekście ich odchyleń od tzw. atmosfery wzorcowej (ISA).

2. Zmiana kształtu i wymiarów geometrycznych kanałów przepływowych i stanu ich powierzchni spowodowana:

- odwracalnym procesem zanieczyszczenia i nieodwracalnym korozyjno-erozyjnym procesem zużycia,

- deformacją kształtu kadłubów zewnętrznych silnika (zmiana luzów promieniowych i osiowych w zespołach wirnikowych),

- uszkodzeniami w następstwie przypadkowego przedostania się do części przepływowej tzw. obcych przedmiotów,

- uszkodzeniami konstrukcji podzespołów regulacji kształtu i wymiarów geometrycznych części przepływowej (upust powietrza, elementy mechanizmu nawrotu oddzielnej turbiny napędowej, regulowana kierownica wlotowa silnika, regulowane kierownice pierwszych stopni sprężarki itp.).

Zagadnienie szczególnej wrażliwości okrętowych turbinowych silników spalinowych na zmienność szeroko rozumianych morskich warunków ich użytkowania nic nie straciło na aktualności od czasu pierwszych aplikacji tego typu napędu, kiedy w 1947 roku silnik „Gatric” produkcji British Associated Electrical Industries Ltd., oznaczony symbolem G1 (1840 kW), wykorzystano jako silnik mocy szczytowej do napędu kutra torpedowego Royal Navy o numerze taktycznym M.G.B.2009 [3, 4]. Stanowił on morską adaptację silnika odrzutowego Metropolitan-Vickers, do którego „dostawiono” oddzielną (swobodną) turbinę napędową. Pierwsze próby okrętu w morzu zaskoczyły konstruktorów bardzo dużą wrażliwością silnika na zanieczyszczenia osadami soli kanałów międzyłopatkowych sprężarki. Po około $20 \mathrm{~h}$ pracy spadek osiągów okrętu był tak duży, iż przerwano dalsze testy. Zaobserwowaną niedoskonałość udało się wówczas usunąć tylko częściowo przez wtrysk wody destylowanej do powietrza na wlocie do sprężarki.

\section{Mechanizm powstawania zanieczyszczeń}

Trudno usuwalne osady zanieczyszczeń, gromadzące się w sposób ciągły na powierzchniach części przepływowej okrętowego turbinowego silnika spalinowego są przyczyną permanentnego spadku mocy i sprawności silnika, przy znacznym pogorszeniu jego cech dynamicznych. Klasyfikację zanieczyszczeń według źródła powstawania i według charakteru oddziaływania na część przepływową przedstawiono na rys. 2 .

Strumień masy czynnika roboczego przepływającego przez część przepływową może wynosić dla współczesnych 
suming that in each consecutive stage of the compressor the temperature of the working medium rises by $15 \div 20$ $\mathrm{K}$ it turns out that the greatest sedimentation rate of the mineral salts is already on the first $4 \div 5$ stages, where the temperature of the sucked pyrosol reaches $350 \div 380$ $\mathrm{K}$. In an engine operating at a given, steady load range, the contamination of the flow part in the form of deposits is limited to the initial stages of the compressor. As the endoscopic examinations show, frequent changes in the engine load facilitate the growth of the evenness of the distribution of the deposits on the intervane channels of the compressor part [7].

The mineral salts transported in the intake air deposit on the elements of the flow part and are bonded with the surface through oil vapors from the labyrinth seals and the products of combustion sucked in with the intake air. The soot and oil vapors, carried by the pyrosol, deposit mainly on the guide vanes and the first $2 \div 3$ stages of the compressor. The thickness of the deposit layer in the compressor part may reach values of tenths of millimeter and the greatest concentration occurs on the guide vanes up to the $2 / 3$ of their height counting from the top - Fig. 3.

The layer of the deposit is composed of the salts of sodium, magnesium, calcium, potassium, carbon compounds and ferric oxides. A part of these components, getting through to the combustor and farther, forms, together with the products of combustion, a layer of a difficult-to-remove deposit on the flow channels of the turbines. The nature and chemical composition of the deposit mainly depends on the physical and chemical properties of the used fuel, the quality of the combustion process, the efficiency of pyrosol filtering at the intake and the frequency of the cleaning procedure of the flow part. Also, the way of cooling of the vanes plays and important role in the mechanism of deposit formation inside the turbines.

The conducted endoscopic examinations have shown a much greater intensity of the contamination of vanes cooled with air fed from the compressor part of the engine. The difference of the particle concentration near the surface of the vane and in the region of the cooling air outlet is a consequence of an uneven field of temperature and the silników okrętowych nawet do $100 \mathrm{~kg} / \mathrm{s}$, co oznacza, że wraz z zasysanym powietrzem przedostają się również znaczne ilości soli wody morskiej. Dla rejonu Morza Bałtyckiego, gdzie zasolenie wody jest niewielkie i wynosi średnio 7,2 $\mathrm{g} / \mathrm{kg}$, a w warstwie przywodnej stężenie (zawartość) soli w powietrzu wynosi $0,1 \mathrm{mg} / \mathrm{kg}$, tylko podczas jednej godziny pracy silnika na nominalnym zakresie obciążenia do części przepływowej przedostaje się około $0,03 \div 0,05 \mathrm{~kg}$ soli [5].

Część soli tylko przepływa przez silnik, część natomiast pozostaje, zanieczyszczając jego kanały przepływowe. Mechanizm powstawania zanieczyszczeń jest następujący.
Fig. 2. The classification of the possible sources of contamination in the air feeding the marine turbine engine

Według źródła powstawania

Pochodzenia naturalnego

- Sól wody

Pył

- Piasek

Cząstki
Według charakteru oddziaływania na część przepływową

- Korozyjne

- Termiczne

Powierzchniowe

- Geometryczne

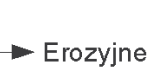

Produkty zużycia

labiryntowych

Kropelki wody morskiej, zawierające w sobie rozpuszczone cząsteczki soli, przedostają się w głąb sprężarki, intensywnie odparowując. Przy założeniu, że w każdym kolejnym stopniu sprężarki temperatura czynnika roboczego podnosi się o $15 \div 20 \mathrm{~K}$ okazuje się, że największa intensywność osadzania się soli mineralnych występuje już na pierwszych $4 \div 5$ stopniach, gdzie temperatury zasysanego pyrozolu osiągają $350 \div 380 \mathrm{~K}$. W silniku pracującym w zadanym, ustalonym zakresie obciążenia zanieczyszczenie części przepływowej w postaci osadów soli ogranicza się do początkowych stopni sprężarki. Jak wykazują wyniki badań endoskopowych, częste zmiany obciążenia silnika sprzyjają zwiększeniu równomierności rozkładu osadu zanieczyszczeń wzdłuż kanałów międzyłopatkowych części sprężarkowej [7].

Sole mineralne transportowane w powietrzu dolotowym do silnika osadzają się na elementach części przepływowej i wiązane są z podłożem parami oleju z uszczelnień labiryntowych oraz produktami spalania zasysanymi do silnika wraz z powietrzem. Sadza i opary olejowe, które niesie zasysany przez silnik pyrozol osadzają się głównie na kierownicy wlotowej i pierwszych $2 \div 3$ stopniach sprężarki. 
phenomenon of thermo diffusion [5]. Figure 4 presents a recorded image of the layer of deposit on the cooled turbine vanes of the Zorya UGT6000 engine.

\section{Corrosive-erosive wear}

The substances contained in the sea pyrosol cause changes to the material properties of the structure of the flow part thus reducing the reliability of the whole engine. The basic reason for the decrease in the durability indexes of the elements of the flow part in the region of the turbines is the corrosion resulting from an aggressive activity of sulfur. Sodium and other alkaline elements contained in the sea salt react in the presence of oxygen and water vapor with sulfur contained in the fuel forming sulfates:

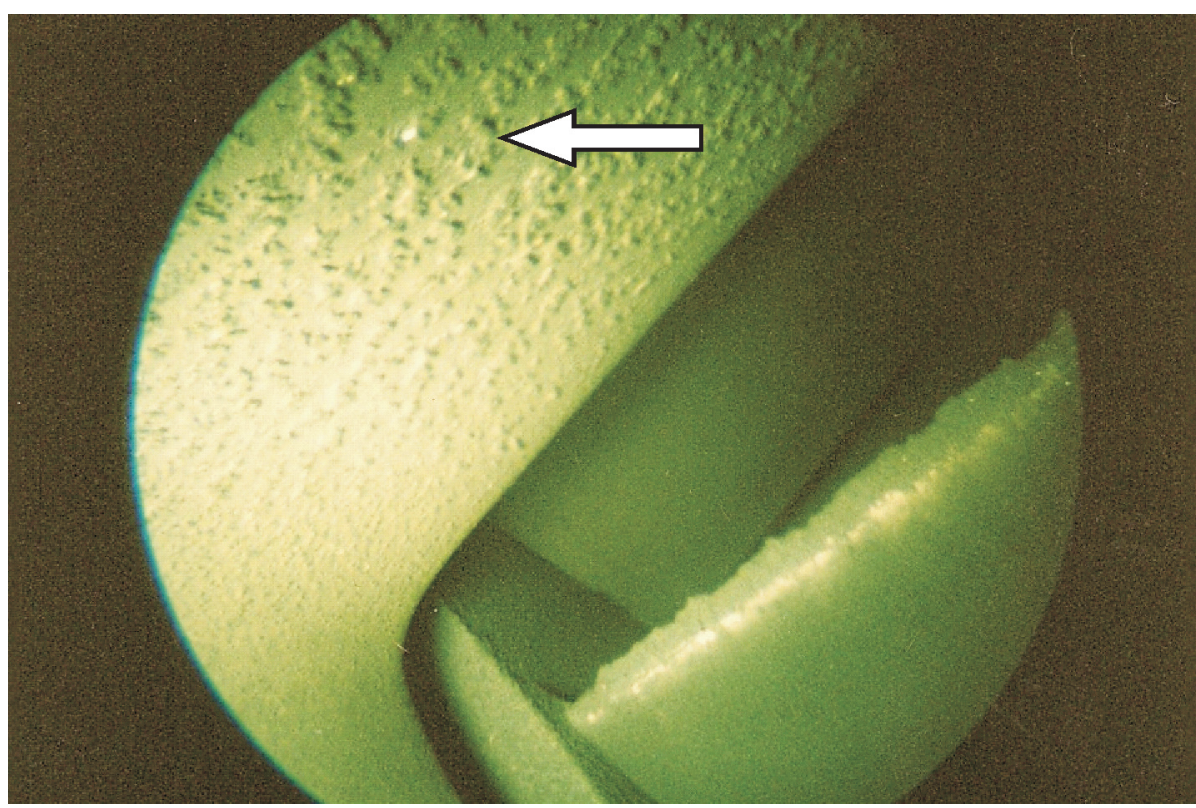

Fig. 3. Deposits on the vanes of the first stage of the low pressure compressor - Zorya UGT3000 engine Rys. 3. Osady zanieczyszczeń na łopatkach kierowniczych 1 st. sprężarki niskiego ciśnienia silnika Zorya typu UGT3000

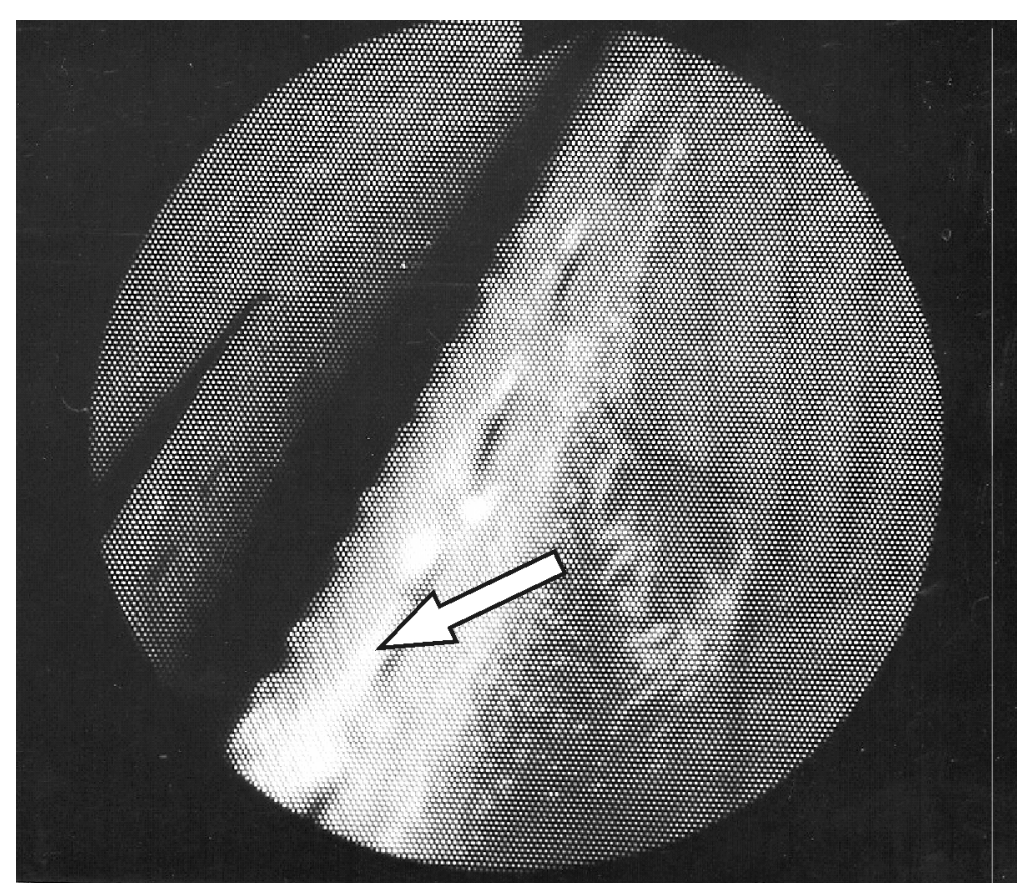

Fig. 4. Deposits in the area of the outlet of cooling air on the cutting edge of the rotor vane -TWC Zorya UGT6000 engine

Rys. 4. Osady zanieczyszczeń w rejonie otworów wylotowych powietrza chłodzacego na krawędzi splywu łopatki wirnikowej TWC silnika Zorya typu UGT6000
Grubość warstwy osadu w części sprężarkowej może osiągać wartości rzędu dziesiątych części milimetra, przy czym największa koncentracja zanieczyszczenia występuje na łopatkach kierowniczych, do 2/3 ich wysokości, licząc od wierzchołka (rys. 3).

\section{Zużycie korozyjno-erozyjne}

Substancje zawarte w zasysanym pyrozolu morskim wywołują zmiany właściwości materiałowych struktury konstrukcyjnej części przepływowej, obniżając niezawodność całego silnika. Podstawową przyczyną obniżenia wskaźników wytrzymałościowych elementów części przepływowej w rejonie turbin jest korozja wywołana agresywnym oddziaływaniem siarki. Sód i inne pierwiastki pochodzenia alkalicznego zawarte $\mathrm{w}$ soli wody morskiej reagują w obecności tlenu i pary wodnej z siarką zawartą w paliwie, tworząc siarczany - wzór (1) i (2).

Występujący w największych ilościach siarczan sodu wraz $\mathrm{z}$ parą wodną tworzy $\mathrm{w}$ produktach spalania kwas siarkowy o silnych właściwościach korozyjnych (korozja niskotemperaturowa) - wzór (3).

Dodatkowo w czasie wzajemnej reakcji powstających chlorków pierwiastków alkalicznych (wanad, sód i potas zawarte w paliwie)

$$
\begin{gathered}
4 \mathrm{NaCl}+2 \mathrm{SO}_{2}+\mathrm{O}_{2}+2 \mathrm{H}_{2} \mathrm{O} \rightarrow 2 \mathrm{Na}_{2} \mathrm{SO}_{4}+4 \mathrm{HCl} \\
\mathrm{NaCl}+\mathrm{H}_{2} \mathrm{O} \rightarrow \mathrm{NaOH}+\mathrm{HCl}
\end{gathered}
$$

Sodium sulfate occurring in the largest amounts together with water vapor forms highly corrosive sulfuric acid in the products of combustion (low temperature corrosion): i związków siarki, w zakresie wysokich temperatur rzędu $1050 \mathrm{~K}$, tworzą się pirosiarczany i trójsiarczany o silnym oddziaływaniu korozyjnym na ochronną warstwę tlenków metalu (korozja wysokotemperaturowa) - rys. 5 [11, 12].

Aktywne chemicznie substancje przemieszczające się wzdłuż części przepływowej silnika naruszają powłokę ochronną jej elementów konstrukcyjnych. Uszkodzenie 


$$
2 \mathrm{Na}_{2} \mathrm{SO}_{4}+2 \mathrm{H}_{2} \mathrm{O} \rightarrow 2 \mathrm{H}_{2} \mathrm{SO}_{4}+2 \mathrm{Na}_{2} \mathrm{O}
$$

Moreover, during the mutual reaction of the forming chlorides of the alkaline elements (vanadium, sodium and potassium contained in the fuel) and the sulfur compounds at high temperatures around $1050 \mathrm{~K}$ pyrosulfates and tri-sulfates are formed that are highly corrosive to the protective metal oxide layers (high temperature corrosion) Fig. 5 [11, 12].

The chemically active substances moving along the flow part of the engine disintegrate the protective layer of the engine structure. Damage of the protective alloy layer based on aluminum, nickel or cobalt begins from the formation of local corrosion spots (sulfur oxides and vanadium oxides) gradually finding their way inside the layer. For example for the material of the turbine vanes coated with the aluminum-nickel-cobalt protective layer, the presence of particles of vanadium and sulfur in the fuel results in a formation of complex compounds such as oxides, sulfides and vanadates. They occur as fusible mixtures depositing powłoki ochronnej, wykonanej ze stopów na osnowie aluminium, niklu lub kobaltu, rozpoczyna się od powstawania lokalnych ognisk korozyjnych (tlenków siarki i tlenków wanadu), systematycznie przenikających w głąb powłoki. Na

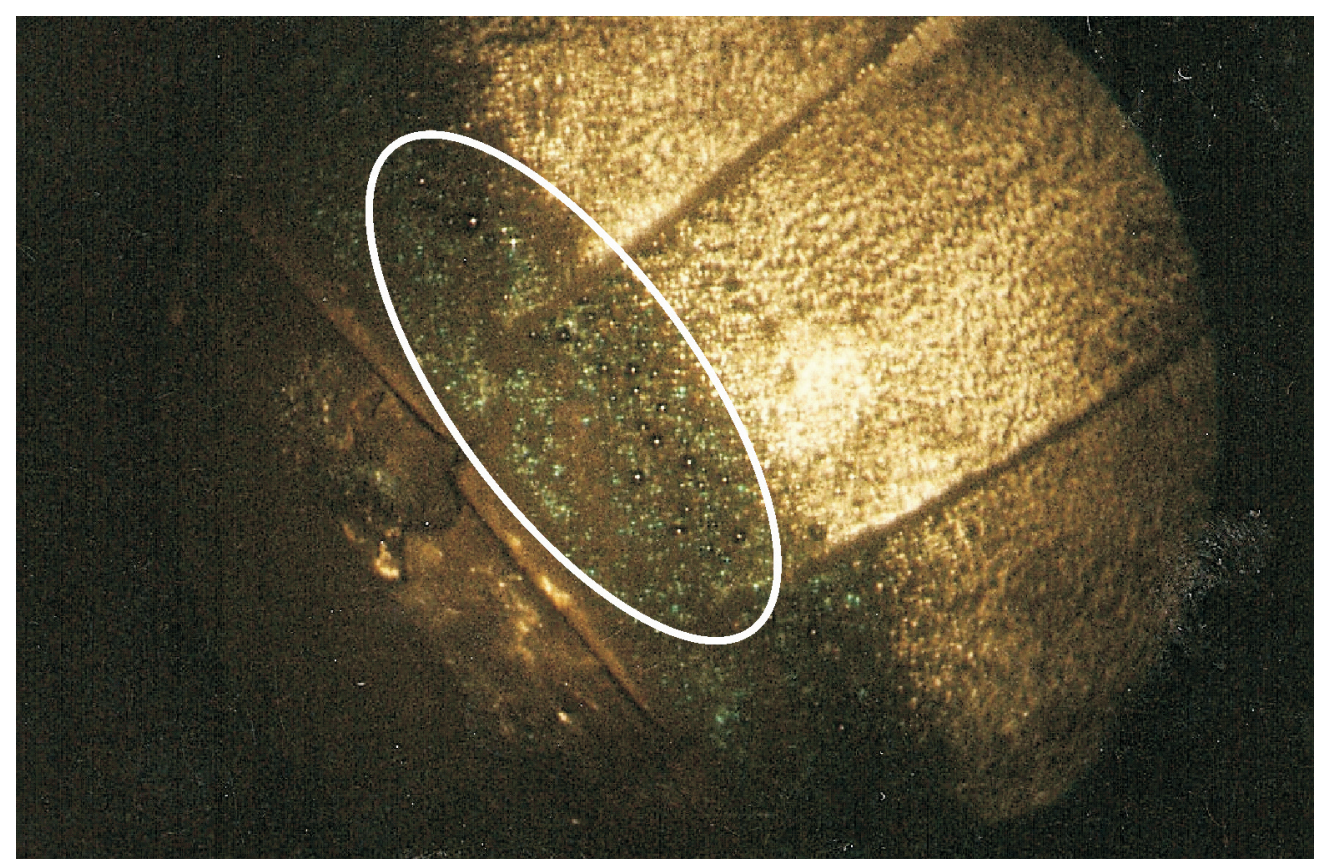

Fig. 5. Characteristic high temperature corrosion bubbles on the guide vanes of the high pressure turbine of the Zorya DE59 engine

Rys. 5. Charakterystyczne pęcherze korozji wysokotemperaturowej na topatkach kierowniczych turbiny wysokiego ciśnienia silnika Zorya typu DE59

przykład dla materiału łopatek turbin z aluminiowo-niklowokobaltową powłoką ochronną obecność w paliwie cząsteczek wanadu i siarki skutkuje w wyniku spalania tworzeniem się złożonych związków chemicznych typu tlenków, siarczków

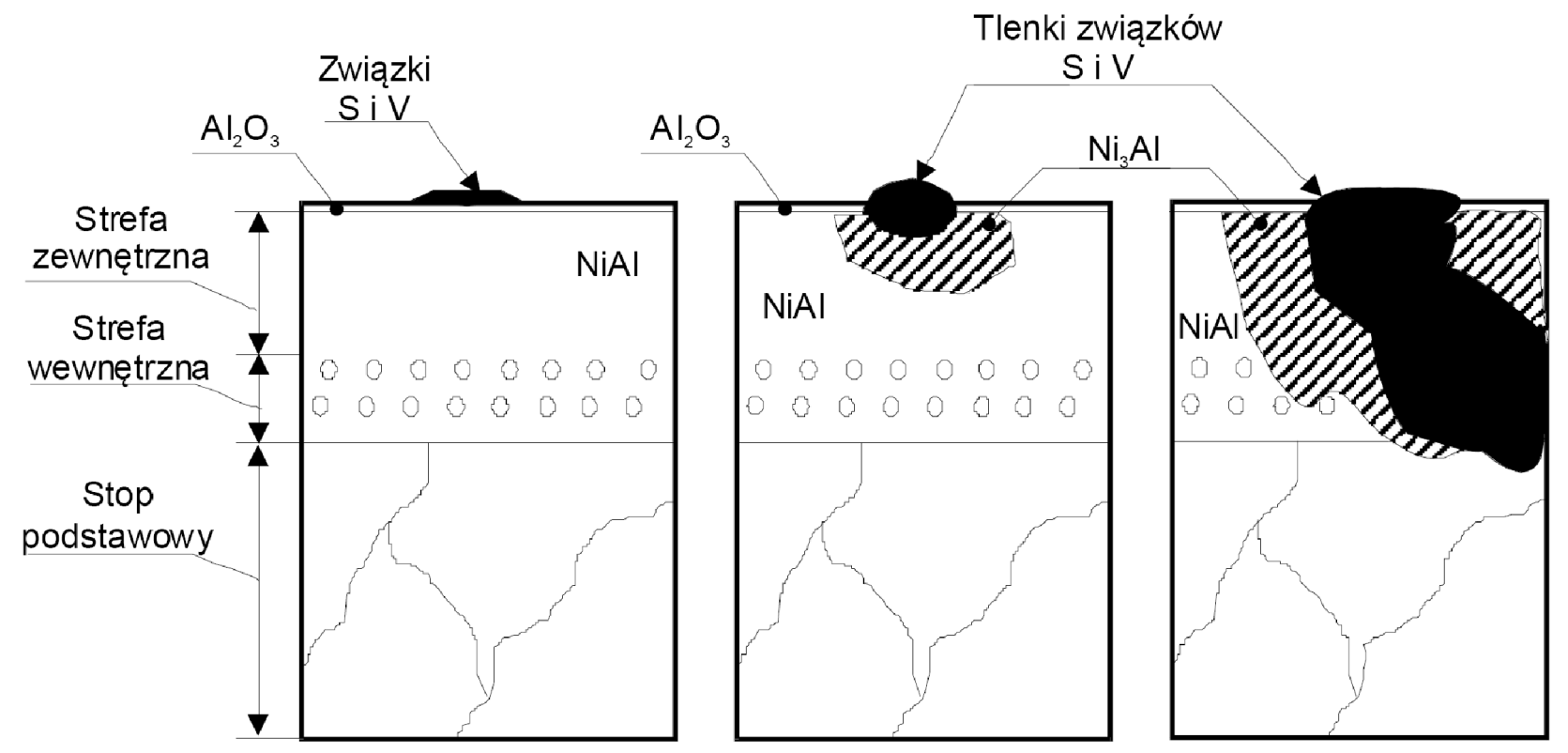

Fig. 6. The mechanism of formation and development of the corrosion of the protective layer of a turbine vane in the Zorya UGT engines Rys. 6. Mechanizm powstawania i rozwoju korozji powłoki ochronnej łopatek turbin w silnikach Zorya typu UGT 
on the surfaces of the blades in the form of a liquid ash (the surface temperature is higher than the melting temperature for these compounds) thus creating good conditions for the disintegration of the protective layer of the aluminum oxide $\left(\mathrm{Al}_{2} \mathrm{O}_{3}\right)$ and preventing its regeneration.

As a result of the chemical reactions occurring on the contact of the protective layer and the oxides of the vanadate and sulfur compounds $\mathrm{Ni}_{3} \mathrm{Al}$ forms of very weak protective properties. This leads to an accelerated corrosion and further permeation of the oxides inside the layer, which leads to deterioration of the strength of the base material. The mechanism of formation and development of the corrosion of the protective layer of a turbine vane in the Zorya UGT engine has been shown in Fig. 6.

The basic types of erosive wear of the flow part of the marine engine are:

- hydro-erosion - where the decisive factor related to the course of the erosion process is the action upon the surface of the flow channels of particles of high kinetic energy,

- abrasive erosion - is a result of the presence of pyrosol of hard particles of industrial dust in the intake air.

The consequence of the wear of the surface of the flow channels of the engine (manifested as local chippings in the surface layer) is the increase in the roughness of the surface at a simultaneous change of the structure of the material. This is particularly the case for surfaces of the vanes where the cutting edges of the intake stages of the compressors wear most rapidly [10]. It is most frequently a result of the abrasive erosion caused by the presence in the mass flow of hard mineral particles and particles of liquid getting to

i wanadków. Występują one w formie niskotopliwych mieszanin osadzających się na powierzchniach łopatek w postaci płynnego popiołu (temperatura powierzchniowa przewyższa temperaturę topnienia tych związków), stwarzając dogodne warunki do naruszenia powłoki ochronnej tlenku aluminium $\mathrm{Al}_{2} \mathrm{O}_{3} \mathrm{i}$ uniemożliwiając tym samym jej regenerację.

W rezultacie reakcji chemicznych zachodzacych na styku powłoki ochronnej i tlenków związków wanadu i siarki tworzy się związek Ni $\mathrm{N}_{3} \mathrm{Al}$, o bardzo słabych właściwościach ochronnych. Prowadzi to do przyspieszenia rozwoju korozji, dalszego przenikania tlenków do wnętrza powłoki i w efekcie do osłabienia właściwości wytrzymałościowych materiału podstawowego. Mechanizm powstawania i rozwoju korozji powłoki ochronnej łopatki turbinowej w silnikach Zorya typu UGT przedstawiono na rys. 6 .

Podstawowe rodzaje zużycia erozyjnego części przepływowej okrętowego turbinowego silnika spalinowego to:

- hydroerozja, gdzie czynnikiem decydującym o przebiegu procesu jest oddziaływanie na powierzchnie kanałów przepływowych cząsteczek cieczy o wysokiej energii kinetycznej,

- erozja ścierna, jako skutek obecności w zasysanym przez silnik pyrozolu twardych cząsteczek pyłów przemysłowych.

Konsekwencją zużycia erozyjnego powierzchni kanałów przepływowych silnika, objawiającego się miejscowymi ubytkami w warstwie wierzchniej, jest zwiększenie chropowatości powierzchni, przy jednoczesnej zmianie struktury (właściwości) materiału konstrukcyjnego w tym miejscu. Dotyczy to w szczególności powierzchni ułopatkowania, gdzie najintensywniej zużywają się krawędzie natarcia łopatek wirnikowych

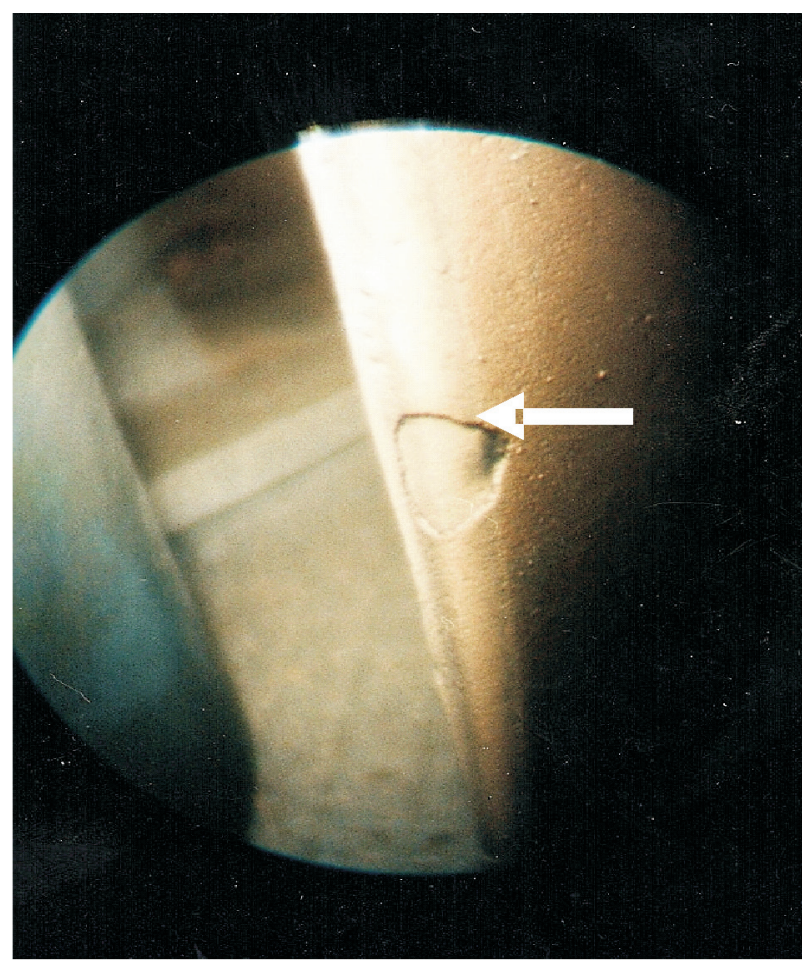

Fig. 7. The cutting edge of the guide vane (TWC Zorya UGT3000 engine) with the visible erosive wear Rys. 7. Krawędź natarcia łopatki kierowniczej TWC silnika Zorya typu UGT3000 z widocznymi śladami zużycia erozyjnego stopni wlotowych sprężarki [10]. Jest ono najczęściej nieuniknionym skutkiem erozji ściernej spowodowanej obecnością w strumieniu przepływającego czynnika roboczego twardych cząsteczek pochodzenia mineralnego oraz cząsteczek cieczy przedostających się do silnika wraz z zasysanym powietrzem. Następuje również znaczny wzrost nierównomierności kształtu i chropowatości powierzchni w rejonie części wklęsłych łopatek.

Często spotykane w czasie zimowego użytkowania okrętowych turbinowych 
the engine with the intake air. A drop in the evenness of the shape of the vanes occurs and increased roughness occurs in their concave parts.

It is quite frequent and hazardous for the engine that during winter operation intense erosive wear occurs of the compressor vanes (intake stages in particular) caused by the presence of ice solids detached from the iced air intakes [7].

The engine turbines are also prone to erosion of the flow channels. This process (abrasive erosion) is related to the formation of hard, charred particles in the products of incomplete combustion. The greatest wear occurs then in the vanes (cutting edges) of the first stage of the high-pressure turbine. Fig. 7 presents the cutting edge of the high-pressure turbine guide vane recorded during the endoscopic examinations.

The intensity of the erosive processes in the flow part is a function of the kinetic energy of the particles, the condition of the surface and the hardness of the construction material as well as the angle of attack of the flowing working medium on the channel. The destructive consequences of the erosive wear are additionally augmented by the corrosion processes. As a consequence, the efficiency of the individual flow machines and the strength properties of the vanes are reduced, which may cause local increase in the tension concentration as well as formation and development of micro cracks until complete destruction (breaking) of the vane.

\section{The influence of the deposit layer on the operat- ing parameters of the compressor and turbines}

The layers of salt, tar and other contaminants that deposit on the surfaces of the flow part of the compressors and turbines with varied intensity modify the shape and geometry of the vanes, the shape of the flow channels and the structure of the surfaces. It is significant, particularly for the compressors that the increase in the values of the roughness of the vane surface reaches several times (see Fig. 3). In a brand new engine the arithmetic average deviation of the profile from the average line of the profile marked as Ra does not exceed one micrometer [11]. During the operation of the engine between overhauls this parameter value grows up to several tens of micrometers [8]. For the turbines the growth in the Ra value triggered by the formation of a deposit may reach up to several micrometers. The results of the increased roughness of the surface is in each case a growth of the flow resistance and as a result - reduced efficiency of the rotor assembly of the contaminated compressors and turbines.

An example dependence of the changes in the efficiency of the flow machines of a turbine engine as a function of the average arithmetic profile deviation from the average line of that profile on the length of the elementary portion le of the rotor and the guide vane surfaces has been shown in Fig. 8.

When analyzing the influence of the contamination of the flow channels on the characteristics of the compressor of a turbine engine we need to distinguish two possibilities that determine these characteristics:

- channel contamination i.e. flow channel upstream or downstream the compressor, silników spalinowych i bardzo niebezpieczne w skutkach jest intensywne zużycie erozyjne łopatek sprężarki, szczególnie stopni wlotowych, wywołane obecnością kryształków lodu odrywanych z oblodzonych wlotów powietrza [7].

Turbiny silnika są również narażone na zużycie erozyjne powierzchni kanałów przepływowych. Proces ten (erozja ścierna) związany jest z tworzeniem twardych, zwęglonych cząsteczek w produktach niecałkowitego spalania paliwa w komorze spalania. W największym stopniu zużywają się wówczas łopatki pierwszego stopnia turbiny wysokiego ciśnienia, szczególnie na ich krawędziach natarcia. Na rysunku 7 przedstawiono, zarejestrowaną w czasie badań endoskopowych silnika w bieżącej eksploatacji, krawędź natarcia łopatki kierowniczej turbiny wysokiego ciśnienia.

Intensywność procesów erozyjnych w części przepływowej silnika jest funkcją energii kinetycznej cząsteczek, stanu powierzchni i twardości materiału konstrukcyjnego oraz kąta natarcia strumienia przepływającego czynnika roboczego na powierzchnię kanału. Destrukcyjne konsekwencje zużycia erozyjnego dodatkowo pogłębia oddziaływanie procesów korozyjnych. W konsekwencji obniżają się sprawności poszczególnych maszyn przepływowych, a także właściwości wytrzymałościowe materiału łopatek, co może spowodować miejscowy wzrost koncentracji naprężeń, powstawanie i rozwój mikropęknięć, aż do całkowitego zniszczenia (ułamania) łopatki.

\section{Wpływ warstwy osadu na parametry pracy sprężarek i turbin}

Warstwa soli, nagaru i innych zanieczyszczeń, które podczas użytkowania silnika $\mathrm{z}$ różnym natężeniem osadzają się na powierzchniach części przepływowej sprężarek i turbin, zmieniają kształt i wymiary geometryczne łopatek, kształt kanałów przepływowych i chropowatość powierzchni. Bardzo istotne, i to szczególnie w odniesieniu do sprężarek, jest kilkakrotne nawet zwiększenie wartości parametrów charakteryzujących chropowatość powierzchni profilu łopatki (patrz rys. 3). W fabrycznie nowym silniku średnie arytmetyczne odchylenie profilu od linii średniej tego profilu, oznaczane jako Ra, nie przekracza jednego mikrometra [11]. W czasie międzyremontowego okresu eksploatacyjnego parametr ten zwiększa swoja wartość nawet do kilkudziesięciu mikrometrów [8]. Dla turbin wzrost wartości Ra wywołany powstawaniem osadu wynosić może nawet kilkaset mikrometrów. Rezultatem wzrostu wartości parametrów chropowatości powierzchni jest w każdym przypadku wzrost oporów przepływu i w rezultacie - obniżenie sprawności palisad łopatkowych zanieczyszczonych sprężarek i turbin.

Przykładową zależność zmian sprawności maszyn przepływowych silnika turbinowego, jako funkcję średniego arytmetycznego odchylenia profilu od linii średniej tego profilu mierzone na długości odcinka elementarnego le powierzchni łopatek wirnikowych i kierowniczych przedstawiono na rys. 8.

Rozpatrując wpływ zanieczyszczenia kanałów przepływowych na charakterystykę sprężarki turbinowego silnika 
- contamination of the intervane channels of the compressor.

In the case of contamination of the channels the conditions of interaction of the compressor with the channels are changed and as a result the line of the compressor interaction with the channels shifts towards the boundary of stable operation of the engine. The change of the conditions of compressor operation when the channels are contaminated (filter elements in the intake channels) has been shown in Fig. 9.

From the course of the interaction line on the characteristics it results that following the contamination of the channels drops the efficiency of the compressor, the mass flow of the working medium and the surge margin defined as follows:

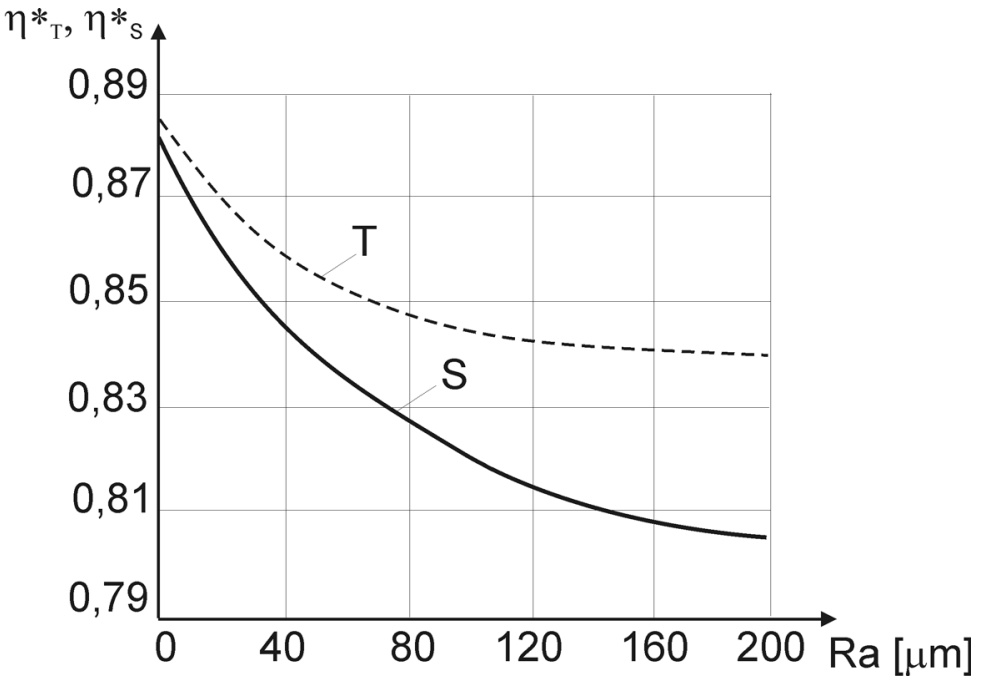

where:

$$
\Delta \mathrm{Z}_{\mathrm{s}}=\left(\mathrm{Z}_{\mathrm{s}}-1\right) 100 \%
$$

$$
Z_{\mathrm{s}}=\frac{\left(\pi_{\mathrm{S}} / \dot{\mathrm{m}}\right)_{\mathrm{gr}}}{\left(\pi_{\mathrm{S}} / \dot{\mathrm{m}}\right)_{\mathrm{p}}}
$$

where: $Z_{\mathrm{s}}$ - coefficient of the surge margin of a compressor, $\left(\pi_{\mathrm{S}} / \dot{\mathrm{m}}\right)_{\mathrm{gr}}-$ ratio of the compression rate of a compressor to the mass flow of the working medium on the boundary of stable operation, $\left(\pi_{S} / \dot{m}\right)_{p}$ - ratio of the compression rate of the compressor to the mass flow of the working medium on the line of steady compressor interaction with the channels.

A reduction of the coefficient of the surge margin of the turbine engine below $5 \%$ results in detaching of the boundary layer on the protuberant parts of the rotor vanes and a pulsation of the flowing air mass $[2,5]$.

When the intervane channels of the compressor get contaminated the conditions of flow of the working medium are changed and the result is an 'entirely different' flow machine. The revolutions decrease and the rotor gets heavier. Isodromes (lines $\mathrm{n}=$ const) on the characteristics of the compressor are delaminated. In Fig. 10 example deformations of the compressor characteristics of a turbine engine have been presented as resulting from the contamination of the intervane and other channels at different variants of the engine load control algorithm (dotted lines). For example, in the case shown in Fig. 10a the controller of the engine load range operates based on the compressor revolutions and the compressor velocity is kept at a set value while the efficiency, the air mass flow of the working medium, the compression rate and the surge margin of the compressor vary.

The contamination of the intervane channels of turbine has similar consequences. Deformation of the intervane channels results in the changes of the optimum ratio of velocity $\mathrm{u} / \mathrm{c}$ in the turbine stage, which means a drop in the efficiency and unit work of decompression of the working medium, and, as a consequence, the reduction of the turbine power output. This, depending on the assumed manner of engine control, triggers adequate deformations of the turbine and compressor characteristics [2, 5, 9].

spalinowego, należy przede wszystkim rozdzielić dwie możliwości zasadniczo ją kształtujące:

- zanieczyszczenie sieci, tzn. kanału przepływowego przed lub za sprężarką,

- zanieczyszczenie kanałów międzyłopatkowych sprężarki.

W przypadku zanieczyszczenia sieci zmianie ulegają warunki współpracy sprężarki z siecią i w rezultacie linia współpracy przesuwa się w kierunku granicy pracy statecznej silnika. Zmianę warunków pracy sprężarki przy zanieczyszczeniu sieci (np. wkładów filtracyjnych odpylaczy powietrza w kanałach dolotowych) przedstawiono na rys. 9.

Z przebiegu linii współpracy na charakterystyce wynika, że wskutek zanieczyszczenia sieci następuje zmniejszenie sprawności sprężarki, strumienia masy przetłaczanego czynnika roboczego, a także zapasu statecznej pracy sprężarki zdefiniowanego zależnością (4), gdzie $Z_{\mathrm{s}}=\frac{\left(\pi_{\mathrm{S}} / \dot{\mathrm{m}}\right)_{\mathrm{gr}}}{\left(\pi_{\mathrm{S}} / \dot{\mathrm{m}}\right)_{\mathrm{p}}}$, a gdzie: $Z_{\mathrm{s}}$ - współczynnik zapasu statecznej pracy sprężarki, $\left(\pi_{\mathrm{S}} / \dot{\mathrm{m}}\right)_{\mathrm{gr}}$ - stosunek sprężu sprężarki do strumienia masy czynnika roboczego na granicy pracy statecznej, $\left(\pi_{\mathrm{S}} / \dot{\mathrm{m}}\right)_{\mathrm{p}}$ - stosunek sprężu sprężarki do strumienia masy czynnika roboczego na linii ustalonej współpracy sprężarki z siecią.

Zmniejszenie współczynnika zapasu statecznej pracy sprężarki silnika turbinowego poniżej 5\% skutkuje odrywaniem się warstwy przyściennej na wypukłych profilach łopatek wirnikowych i pulsacją przetłaczanego strumienia powietrza $[2,5]$.

Przy zanieczyszczeniu kanałów międzyłopatkowych sprężarki zmianie ulegają warunki przepływu czynnika roboczego i mamy do czynienia z zupełnie ,inną" maszyną przepływową. Następuje spadek prędkości obrotowej wirnik staje się ,cięższy”. Izodromy (linie $n=$ const) na 


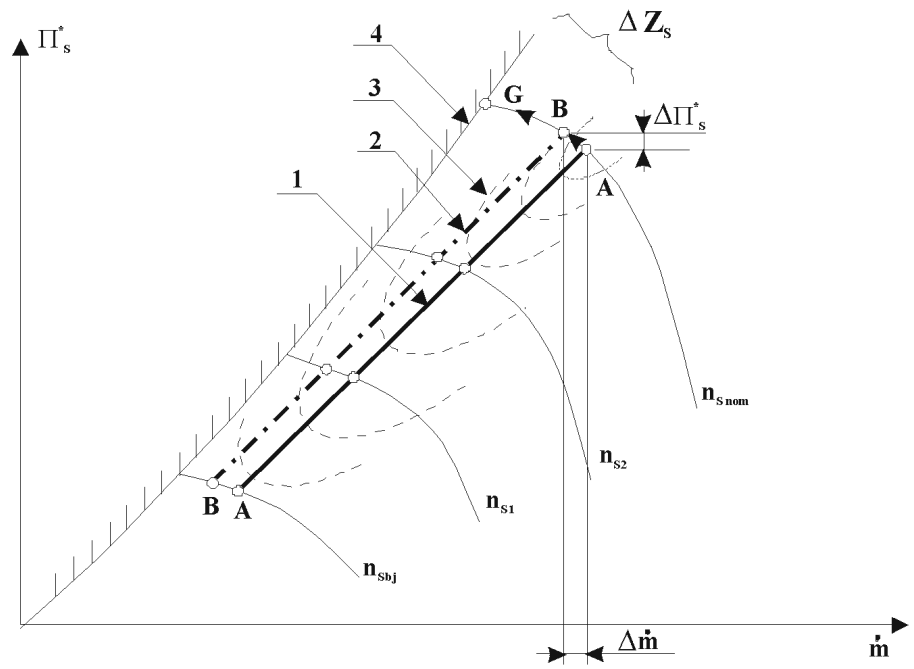

In multishaft engines the interpretation of the influence of the contamination of the flow part on the characteristics of the individual flow machines is a much more complex issue. A strong gas-dynamic bond of the rotor assemblies of the compressors and turbines operating at different velocity ranges results in their peculiar mutual interaction. This a)

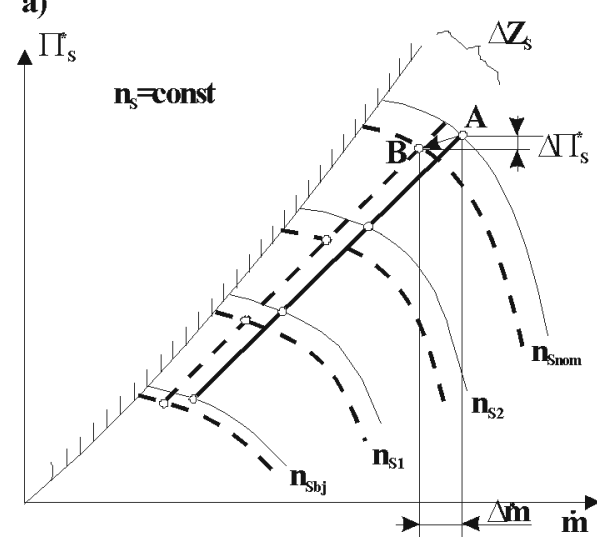

c)

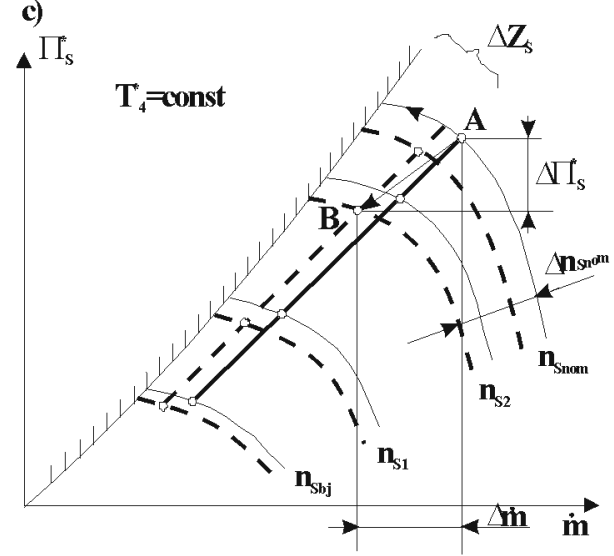

b)

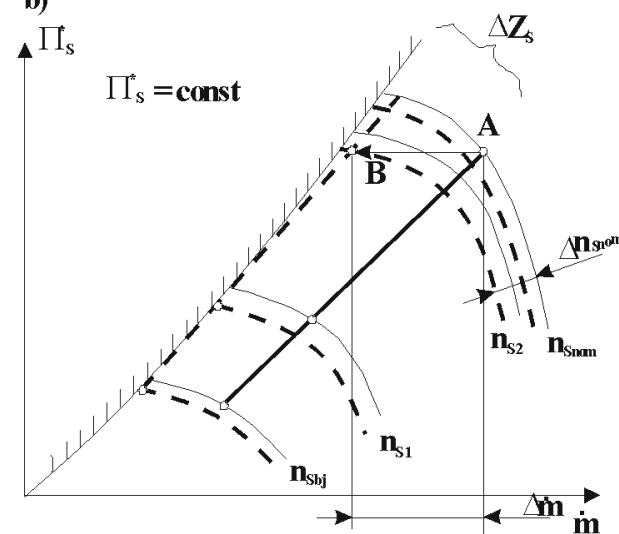

d)

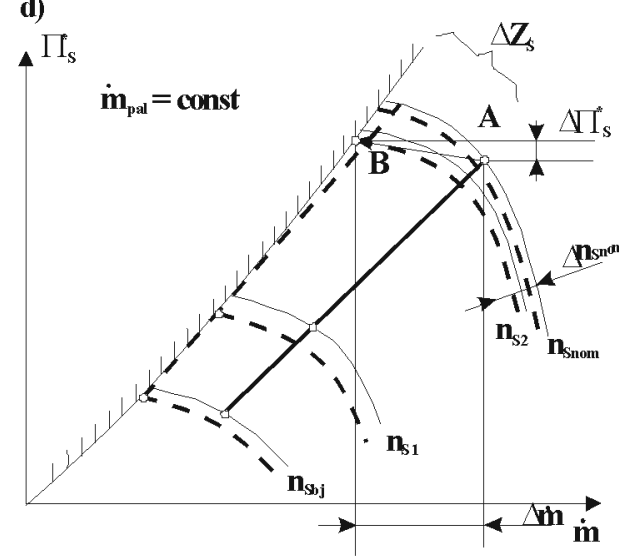

Fig. 10. Changes of the compressor characteristics triggered by the contamination of the intervane and other channels at different variants of the engine load range control algorithms: a) $\mathrm{n}_{\mathrm{s}}=$ const, b) $\pi_{\mathrm{s}}{ }^{*}=$ const, c) $\mathrm{T}_{4}^{*}=$ const, d) $\dot{\mathrm{m}}_{\mathrm{pal}}=$ const, $\mathrm{n}_{\mathrm{s}}$ - rotor velocity, $\pi_{\mathrm{s}}{ }^{*}$ - compression rate, - air mass flow A, B - the points of interaction of the compressor with the channels

Rys. 10. Zmiany charakterystyki sprężarki wywołane zanieczyszczeniem jej kanałów międzyłopatkowych i sieci, przy różnych wariantach algorytmu sterowania zakresem obciążenia silnika: a) wedlug $n_{S}=$ const, b) wedtug $\pi_{S}{ }^{*}=$ const, c) wedlug $T_{4}^{*}=$ const, d) wedlug $\dot{\mathrm{m}}_{\mathrm{pal}}=$ const, $n_{S}-$ prędkość obrotowa, $\pi_{S}{ }^{*}$ - spręż, - strumień masy powietrza A, B-punkty wspótpracy sprężarki z siecia
Fig. 9. Change of the operation range on the characteristics phen the channels are contaminated - the line of interaction determined through calculations, 列 3 - the line of compressor efficiency, 4 - the velocity, $\pi_{\mathrm{s}}{ }^{*}$ - compression rate, $\dot{\mathrm{m}}$ - air mass flow, $\mathrm{A}, \mathrm{B}-$ the points of interaction of the compressor and the turbine

Rys. 9. Zmiana zakresu pracy na charakterystyce sprężarki przy zanieczyszczeniu sieci: 1 - linia wspótpracy ustalonej $w$ warunkach obliczeniowych, 2 - linia wspótpracy ustalonej w warunkach zanieczyszczenia sieci, 3 - linia sprawnosi efektywnej spręzarki, 4 - granica pracy statecznej spremasy powietrza, $A, B$ - punkty wspótpracy spręzarki i turbiny na zakresie mocy nominalnej i biegu jałowego, $G$ - przekroczenie granicy pracy statecznej sprężarki

charakterystyce sprężarki ulegają rozwarstwieniu. Na rysunku 10 przedstawiono poglądowo przykładowe deformacje charakterystyki sprężarki silnika turbinowego spowodowane zanieczyszczeniem jej kanałów międzyłopatkowych i sieci, przy różnych wariantach realizowanego algorytmu sterowania obciążeniem silnika (linie przerywane). Przykładowo, w przypadku przedstawionym na rys. $10 \mathrm{a}$ regulator zakresu obciążenia silnika sprzężony jest z prędkością obrotową sprężarki i jest ona utrzymywana na zadanej wartości, przy różnej sprawności, strumieniu masy czynnika roboczego, sprężu oraz mniejszym zapasie statecznej pracy sprężarki.

Zanieczyszczenie kanałów międzyłopatkowych turbin powoduje podobne skutki. Deformacja kanałów miedzyłopatkowych powoduje zmiany optymalnego stosunku prędkości u/c w stopniu turbiny, co oznacza spadek sprawności i jednostkowej pracy rozprężania czynnika roboczego, a w konsekwencji - spadek mocy turbiny. Wywołuje to, w zależności od przyjętego sposobu regulacji silnika, adekwatne deformacje charakterystyk sprężarki i turbiny $[2,5,9]$.

W silnikach wielowałowych interpretacja wpływu zanieczyszczenia części przepływowej na 
interaction may have a boosting or damping effect and its course is determined with the shape of the lines on the static and dynamic characteristics of the engine resulting from its design, dynamic features and assumed way of engine load control $[6,12]$.

\section{Conclusions}

The most probable region of contamination of the flow part of a marine turbine engine are the first stages of the low pressure compressor (the main component of the deposit is salt) and the high pressure turbine where the contamination can be a result of the presence of salt and oil products at the same time.

Corrosive and erosive wear of the flow part of the engine causes, similarly to its contamination, a deformation of the shape and geometry of the intervane channels as well as increases the roughness of their surface. This leads to a reduction of the efficiency of the individual flow machines, deterioration of their dynamic, kinematic and thermodynamic characteristics, which is reflected in a reduction of the values of the basic engine parameters.

Additionally the strength properties of the construction material of the vanes are significantly reduced, which may cause local increase in the tension concentration as well as formation and development of micro cracks until complete destruction (breaking) of the vane.

Paper reviewed/Artykut recenzowany charakterystyki poszczególnych maszyn przepływowych jest zagadnieniem znacznie bardziej skomplikowanym. Silna więź gazodynamiczna zespołów wirnikowych sprężarek i turbin, pracujących w różnych zakresach prędkości obrotowej, skutkuje szczególnym sposobem ich wzajemnego oddziaływania. Oddziaływanie to może mieć charakter wspomagający lub dławiący, a jego przebieg zdeterminowany jest kształtem linii na charakterystykach statycznych i dynamicznych silnika, wynikających z jego formy konstrukcyjnej, cech dynamicznych oraz przyjętego sposobu sterowania zakresem obciążenia $[6,12]$.

\section{Podsumowanie}

Najbardziej prawdopodobnym rejonem zanieczyszczenia części przepływowej okrętowego turbinowego silnika spalinowego są pierwsze stopnie sprężarki niskiego ciśnienia, dla których głównym składnikiem osadu jest sól oraz turbina wysokiego ciśnienia, gdzie zanieczyszczenia mogą być spowodowane jednoczesną obecnością soli i produktów ropopochodnych.

Zużycie korozyjne i erozyjne części przepływowej silnika powoduje, podobnie jak w sytuacji jej zanieczyszczenia, deformację kształtu oraz zmianę wymiarów geometrycznych kanałów międzyłopatkowych, a także wzrost chropowatości powierzchni. Prowadzi to do obniżenia sprawności poszczególnych maszyn przepływowych, pogorszenia ich charakterystyk dynamicznych, kinematycznych i termodynamicznych, co ma swoje odzwierciedlenie w zmniejszaniu się wartości parametrów podstawowych silnika.

Dodatkowo zdecydowanie obniżają się właściwości wytrzymałościowe materiału konstrukcyjnego łopatek, co może spowodować zwiększenie miejscowych koncentracji naprężeń, powstawanie i rozwój mikropęknięć, aż do całkowitego zniszczenia (ułamania) łopatki.

\section{Bibliography/Literatura}

[1] Cohen H., Rogers G.F.C., Saravanamuttor H.I.H.: Gas turbine theory. Fourth edition. Longman Scientific \& Technical, New York 1996.

[2] Hardin J.R. et al.: A gas turbine condition - monitoring system. Naval Engineers Journal, November, USA 1995.

[3] Hemingway B.E.: Surge and its implications in gas turbines. The Oil Engine and Gas Turbine, October, England 1961.

[4] Hemingway B.E.: A new British naval gas turbine. The Oil Engine and Gas Turbine, October, England 1959.

[5] Korczewski Z.: Metoda diagnozowania części przepływowej okrętowego turbinowego silnika spalinowego w eksploatacji. AMW, Gdynia 1992.

[6] Korczewski Z.: Identyfikacja procesów gazodynamicznych w układzie sprężarkowym okrętowego turbinowego silnika spalinowego dla potrzeb diagnostyki. AMW, Gdynia 1999.

[7] Korczewski Z.: Endoskopia silników okrętowych. AMW, Gdynia 2008.

[8] Marinai L., Probert D., Singh R.: Prospects for aero gas-turbine diagnostics: a review. Applied Energy. Elsevier. Volume 79, Issue 1, September 2004, p. 109-126.

[9] Mathioudakis K., Aretakis N., Y fantis E.: A possibility for onboard training for marine gas turbine performance monitoring

and diagnostics. Conference Proceedings MECON 2006, 29 August - 1 September 2006, Hamburg.

[10] Tsalavoutas A., Mathioudakis K., Stamatis A., Smith M.K.: Identifying faults in the variable geometry system of a gas turbine compressor. ASME Journal of Turbomachinery, Vol. 123, No. 1, January 2001, p. 33-39.

[11] Dokumentacja techniczna i eksploatacyjna okrętowych turbinowych silników spalinowych Zorya typu UGT oraz General Electric typu LM2500.

[12] Sprawozdania z badań diagnostycznych tłokowych i turbinowych silników spalinowych eksploatowanych na okrętach MW RP. Prace naukowo-badawcze zlecane przez Logistykę MW RP oraz Departament Zaopatrywania Sił Zbrojnych RP. AMW Gdynia 1992-2008.

Zbigniew Korczewski, DSc., DEng. - professor in the Faculty of Ocean Engineering and Ship Technology at Gdansk University of Technology. Prof. dr hab. inż. Zbigniew Korczewski - profesor na Wydziale Oceanotechniki i Okrętownictwa Politechniki Gdańskiej.

e-mail: z.korczewski@gmail.com

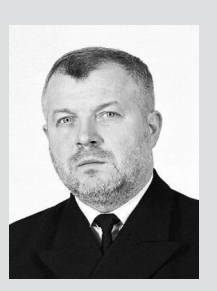

